Journal of Southeast Asian Studies, 48(1), pp 6-30 February 2017.

(C) The National University of Singapore, 2017 doi:10.1017/S002246341600045X

\title{
Drunken poets and new women: Consuming tradition and modernity in colonial Vietnam
}

\author{
Gerard Sasges
}

This article uses the lens of alcohol as a means of exploring the experiences and anxieties of Vietnamese 'colonial modernity' and the way it was mutually constituted with 'colonial tradition'. The production, consumption, and meaning of alcohol in Vietnam were all profoundly altered as the state's contested attempts to control the market for rice liquor interacted with the growing availability of imports like wine, champagne, and cognac. While these new products would become ideal symbols of modernity and markers of distinction, at the same time reinvented traditions surrounding what the French called 'native' and the Vietnamese called 'our' alcohol would become linked to evolving notions of community and nation.

In a 1933 issue of a popular Hanoi journal, a two-panel cartoon shows two men about to enjoy a drink together. ${ }^{1}$ They sit at a table draped in a spotless white tablecloth, ostentatiously relaxed on European-style upholstered chairs. In the first panel, one man whose wrinkles announce him as the elder wears the traditional Vietnamese dress of long shirt and turban (áo dài khăn đóng). ${ }^{2}$ The other is bareheaded, his

Gerard Sasges is Assistant Professor at the Department of Southeast Asian Studies, National University of Singapore. Correspondence in connection with this article should be addressed to: gerard.sasges@nus. edu.sg. The author would like to thank Thái Lương, Nguyễn Thanh Hải, Phan Quang Minh, and Hoàng Gia Thư for their observations on Vietnamese drinking culture, among many other things, and their introductions to others involved in the alcohol trade. He would also like to thank Bruce Lockhart, Thái Vĩnh Trân, John Scott Hess, Martina Nguyen, and the two anonymous reviewers of the Journal of Southeast Asian Studies for their comments on earlier drafts of the article. A version of this article was presented at the 40th Annual Meeting of the French Colonial Historical Society, Siem Reap, 25-28 June 2014. Research for the article was carried out in part thanks to funding from the National University of Singapore (WBS: R-117-000-030-133). This article is based on research at the Vietnamese National Archives One in Hanoi (abbreviated as VNA1), the Vietnamese National Archives Two in Ho Chi Minh City (VNA2), the Cambodian National Archives in Phnom Penh (CNA), the French National Overseas Archives in Aix-en-Provence (FNOA) and the national libraries of Vietnam (Hanoi) and France (Paris). It also makes extensive use of the online archives of the Người Việt Thư Viện at http://issuu.com/nvthuvien. All translations are my own.

1 Phong Hoá 71 (3 Nov. 1933): 2-3; http://issuu.com/nvthuvien/docs/ph_071_03_nov_1933? $\mathrm{e}=5818453 / 2999036$.

2 The use of 'Vietnamese' here is anachronistic. During colonial rule, the French divided the spaces that now form the Socialist Republic of Vietnam into the three 'countries' (pays) of Tonkin, Annam, and Cochinchina, which, together with Laos and Cambodia formed French Indochina. However, 'Vietnam' and 'Vietnamese' remain the simplest terms for referring to the spaces, peoples, and cultures that are 
cropped hair marking him as a modern young man. In their hands they hold not the small ceramic or earthenware cups used to drink rice liquor, but rather glasses filled with a liquid whose dark colour reveals it as red wine. One of the men says, 'And now you should drain your glass with me. Okay, cheers!...."3 The novelty of their exchange can be seen in multiple ways. For one, the Vietnamese word for the wine they're drinking is ru'ợ vang, with the loan word 'vang' - from the French 'vin' - attesting to its recent adoption into local culture. In addition, the speaker refers to himself using the newly popularised pronoun 'tôi', asserting an individualism and an equality impossible with the pronoun pairs that Vietnamese usually use to link interlocutors and encode hierarchies of age, gender, and status.

In the first panel, the two men smile broadly, obviously happy to experiment with new forms of socialising and the novel custom of touching glasses before drinking. Yet in the second panel, the two men stare in dismay at the broken glasses in their hands, speechless as wine cascades onto the white tablecloth below. The shock of the meeting, it appears, was too great. Thus one simple cartoon encapsulates multiple ways Vietnamese experienced the rapid changes in language, dress, comportment, consumption, and sociability that formed part of a colonial modernity. Yet it also reveals the anxieties these changes provoked, along with the lingering fear that modernity's promises of progress, individualism, and equality might in the end prove as broken and empty as the glasses they held in their hands.

\section{Colonial modernity, colonial tradition}

The article that follows uses the lens of alcohol as a means of exploring the experiences and anxieties of Vietnamese 'colonial modernity' and the way it was mutually constituted with what might be called a 'colonial tradition'. ${ }^{4}$ Since the 1990s, scholars have used the concept of colonial modernity as a way to explore not just the role colonialism played in the construction of culture, but also the way local culture shaped colonialism. ${ }^{5}$ In their introduction to their 1999 collection, Colonial modernity in Korea, Gi-Wook Shin and Michael Robinson argued that the concept was particularly relevant to Korea, where the division of the country in 1945 and the resulting politicisation of scholarship served to limit the kinds of questions historians could pursue or the answers they might find. Colonial modernity, they argued, provides a different conceptual framework that 'emphasizes dynamism, multiple possibilities and causal connections, and various (often competing) ideas of nation, modernity, and colonialism'. ${ }^{6}$ The concept can also be applied usefully to

the subject of this article. For varieties of 'Vietnam' in the past, see Keith Taylor, 'Surface orientations in Vietnam: Beyond histories of nation and region', Journal of Asian Studies 57, 4 (1998): 949-78. For the different ideas of space and nation in the colonial period, see Christopher E. Goscha, Going Indochinese: Contesting concepts of space and place in French Indochina (Honolulu: University of Hawai'i Press, 2012).

3 'Thế nào anh cũng phải uống cạn với tôi cốc rượu này. Nào ta chạm cốc ...'.

4 As in Eric J. Hobsbawm and Terence O. Ranger's well-known concept questioning the origin of many 'traditions' in The invention of tradition, ed. Hobsbawm and Ranger (Cambridge: Cambridge University Press, 1983).

5 See Formations of colonial modernity in East Asia, ed. Tani E. Barlow (Durham: Duke University Press, 1997).

6 Gi-Wook Shin and Michael Robinson, 'Introduction: Rethinking colonial Korea', in Colonial 
Vietnam, where the contested processes of decolonisation and civil war continue to shape the writing of its colonial and post-colonial pasts. ${ }^{7}$

For Vietnam, the defining work on cultural politics under colonial rule remains David Marr's Vietnamese tradition on trial. ${ }^{8}$ In it, Marr documents a range of issues, from morality instruction, to the popularisation of the quốc ngũ Romanised script, to debates over women's rights (nũ quyền) and the 'new woman' (đàn bà mới). While Marr's work remains unmatched in its depth and breadth, its analysis is shaped by a telos whose endpoint is 1945 and Vietnam's declaration of independence under communist leadership. More recently, scholars have begun to approach the colonial period in new ways. Print capitalism and the related issues of language and translation have proved fruitful topics, with Christopher Goscha, Philippe Peycam, and Peter Zinoman using such issues to move beyond dichotomies of collaboration and resistance and instead explore the period's complex interactions between culture and colonialism. ${ }^{9}$ Erica Peters has explored the ways in which tastes, practices, and identities evolved in the colonial period as consumers gained access to new goods and ideas from around the world at the same time as markets for local products like rice liquor and fish sauce came under increasingly strict control. ${ }^{10}$ Shawn McHale and Judith Henchy, among others, have examined gender and its contested role in the construction of the modern. ${ }^{11}$ Other scholars have used issues as varied as rickshaws, midwifery, sports, and hill stations to contribute to an increasingly rich understanding of colonial modernity in Vietnam. ${ }^{12}$

modernity in Korea, ed. Gi-Wook Shin and Michael Robinson (Cambridge, MA: Harvard University Press, 1999), p. 2.

7 For example, see Ed Miller's summary of the 'Taylor-Buzzanco Debate' over the historiography of the Indochina conflicts. Edward Miller, 'War stories: The Taylor-Buzzanco Debate and how we think about the Vietnam War', Journal of Vietnamese Studies 1, 1-2 (2006): 453-84.

8 David G. Marr, Vietnamese tradition on trial, 1920-1945 (Berkeley: University of California Press, 1984).

9 Christopher Goscha, "The "modern barbarian": Nguyen Van Vinh and the complexity of colonial modernity in Vietnam', European Journal of East Asian Studies 3, 1 (2004): 135-69; Philippe Peycam, The birth of Vietnamese political journalism: Saigon, 1916-1930 (New York: Columbia University Press, 2012); Peter Zinoman, Vietnamese colonial republican: The political vision of Vũ Trong Phung (Berkeley: University of California Press, 2013).

10 Erica J. Peters, Appetites and aspirations in Vietnam: Food and drink in the long nineteenth century (Lanham, MD: Altamira, 2012). See also Erica J. Peters, 'Resistance, rivalries, and restaurants: Vietnamese workers in interwar France', Journal of Vietnamese Studies 2, 1 (2007): 109-43.

11 Shawn McHale, 'Printing and power: Vietnamese debates over women's place in society, 1918-1934', in Essays into Vietnamese pasts, ed. Keith W. Taylor and John K. Whitmore (Ithaca: SEAP, Cornell University, 1995), pp. 173-94; Judith Henchy, 'Vietnamese new women and the fashioning of modernity', in France and 'Indochina': Cultural representations, ed. Kathryn Robson and Jennifer Yee (Lanham: Lexington, 2005), pp. 121-38.

12 H. Hazel Hahn, 'The rickshaw trade in colonial Vietnam, 1883-1940', Journal of Vietnamese Studies 8, 4 (2013): 47-85; Thuy Linh Nguyen, 'French-educated midwives and the medicalization of childbirth in colonial Vietnam', Journal of Vietnamese Studies 5, 2 (2010): 133-82; Agathe Larcher-Goscha, 'Sports, colonialisme et identités nationales: premières approches du "corps à corps colonial" en Indochine (1918-1945)', in De l'Indochine à l'Algérie: La jeunnesse en movement de deux côtés du miroir colonial, 1940-1962, ed. Nicolas Bancel, Daniel Denis and Youssef Fates (Paris: La Découverte, 2003), pp. 13-31; Eric Jennings, Imperial heights: Dalat and the making and undoing of French Indochina (Berkeley: University of California Press, 2011). On 'post-colonial modernity' in Vietnam, see Van Nguyen-Marshall, Lisa B. Welch Drummond and Danièle Bélanger, The reinvention of distinction: Modernity and the middle class in urban Vietnam (London: Springer, 2012). 
Nevertheless, the potential of the approach remains to be fully realised. One example is a 2007 article that focused on 'Lý Toét', a sort of country bumpkin scholarofficial who became a stock figure in 1930s illustrations and satire. ${ }^{13}$ In it, George Dutton argues that through Lý Toét and his encounters with things like bicycles, fans, telephone poles, and underground sewer systems, educated urban Vietnamese were able simultaneously to ridicule their less modern countrymen and women while normalising their own discomfort in a rapidly changing world. Yet like many others, Dutton's article leaves the impression of a clear dichotomy between tradition and modernity. Rather than highlight the potential Vietnamese found in the simultaneous embrace of both, the article focuses on the anxieties that emerged from an over-hasty transition from one pole to its supposed opposite. At the same time, gender or the ways new identities were shaped by racism and other forms of violence remain undiscussed.

In this article, I argue that alcohol is a particularly useful way of exploring the elaboration of colonial modernity and tradition in Vietnam. Few things are as intimately tied to culture and identity as alcohol. In his 1957 collection Mythologies, Roland Barthes highlighted the symbolic value of red wine in French culture and its role in the reproduction of bourgeois values. Wine, he observed, was a particularly rich object of analysis, supporting a 'varied mythology which does not trouble about contradictions' ${ }^{14}$ Later, Pierre Bourdieu explored the many opportunities alcohol and its consumption presented for the pursuit of distinction. ${ }^{15}$ Yet, like Barthes, he acknowledged alcohol's multivalent meanings and the possibilities they opened to contest dominant norms:

The art of eating and drinking remains one of the few areas in which the working classes explicitly challenge the legitimate art of living. In the face of the new ethic of sobriety ... peasants and especially industrial workers maintain an ethic of convivial indulgence.

As a result, they remain

capable of entering into the generous and familiar - that is, both simple and free relationship that is encouraged and symbolised by eating and drinking together, in a conviviality which sweeps away restraints and reticence. ${ }^{16}$

In Vietnam as in France, alcohol was a powerful symbol with multiple, often contradictory, meanings intimately tied to an evolving modernity.

Industrial capitalism and state power were an integral part of this evolving modernity. Around the world, drinking cultures were being shaped by new technologies, expanding global markets, and states that sought to harness industrial capacity to national or imperial ends. ${ }^{17}$ In France, Louis Pasteur's ground-breaking research on

13 George Dutton, 'Lý Toét in the city: Coming to terms with the modern in 1930s Vietnam', Journal of Vietnamese Studies 2, 1 (2007): 80-108.

14 Roland Barthes, Mythologies, trans. Annette Lavers (New York: Farrar, Straus \& Giroux, 1991), p. 58.

15 See, for example, the schema labelled 'Figure 9: The Food Space'. Pierre Bourdieu, Distinction: A social critique of the judgment of taste, trans. Richard Nice (Cambridge, MA: Harvard University Press, 1996), p. 186.

16 Bourdieu, Distinction, p. 179.

17 For an overview, see Gina Hames, Alcohol in world history (London: Routledge, 2012). 
fermentation and the industrial production of wine and beer was carried out in the context of the nation's rivalry with Germany. ${ }^{18}$ In Russia, the imperial government raised one-quarter of its revenue through a vodka monopoly that made use of the productive capacity unleashed by new distilling technologies. ${ }^{19}$ And in Japan, the state promoted the creation and growth of an entirely new industry - beer brewing after its planners identified the beverage as a potentially lucrative export product. ${ }^{20}$ In Vietnam, this confluence of industrial and state power was to take a uniquely pernicious form after 1897 with the colonial regime's decision to erect a monopoly on the production and sale of distilled rice liquor: what the French called 'native alcohol' (alcool indigène) and the Vietnamese rượu trắng, rượu dế, or simply rượu. ${ }^{21}$ Thanks to the monopoly, Vietnamese were compelled to replace their traditionally distilled liquor with heavily taxed, insipid alcohol produced in French-owned factories. Alcohol thus provides a clear example of how truly colonial this colonial modernity could be and its implication in systems of capitalist exploitation and state repression.

While this article focuses on the late colonial period, its scope ranges from the pre-colonial up to the present day. Any attempt to reconstruct the production, distribution, and consumption of alcohol in the pre-colonial period is necessarily fraught. Yet the effort is justified by the need to understand the challenges posed by colonial modernity and the way traditions were reconfigured, reshaped, and assumed new meanings. To better understand alcohol in Vietnam's past, this article draws from a range of sources, from archival documents to satirical cartoons, from colonial novels to classical poetry, colloquial sayings, and observations conducted during drinking sessions in the villages of Vietnam. One important source for the colonial period is the journal mentioned at the beginning of this article, Phong Hoá ('Mores', 193236). One of the most popular and influential journals of the late colonial period, Phong Hoá was the vehicle for the Tự Lực Văn Đoàn (Self-Reliant Literary Group), a diverse group of authors, critics, and activists who in their stories, articles, editorials, and cartoons actively engaged with the key social, political, and cultural issues of the day. ${ }^{22}$ Perhaps more than any other journal of the time, Phong Hoá provides a

18 Louis Pasteur, Études sur le vin, ses maladies, causes qui les provoquent, procédés nouveaux pour le conserver et pour le vieillir (Paris: F. Savy, 1873); Louis Pasteur, Etudes sur la bière, ses maladies, causes qui les provoquent, procédé pour la rendre inaltérable; avec une théorie nouvelle de la fermentation (Paris: Gauthier-Villars, 1876).

19 Alexander M. Michelson, 'Revenue and expenditure', in Russian public finance during the war: Revenue and expenditure, ed. Alexander Michelson, Paul Apostol and Michael Bernatzky (New Haven: Yale University Press, 1928), pp. 39-40. See also David Christian, Living water: Vodka and Russian society on the eve of emancipation (Oxford: Clarendon Press, 1990).

20 Jeff Hass, "They have no idea what it is to run a malthouse": A Wisconsin beer maker in Japan', Wisconsin Magazine of History 87, 2 (2003-4): 14-29.

21 Gerard Sasges, Imperial intoxication: Alcohol and the making of colonial Indochina (University of Hawai'i Press, forthcoming); Gerard Sasges, 'State, enterprise, and the alcohol monopoly in colonial Vietnam', Journal of Southeast Asian Studies 43, 1 (2012): 133-57.

22 For more on the Tự Lực Văn Đoàn in English, see Martina Nguyen's forthcoming 'The Self-Reliant Literary Group (Tự Lực Văn Đoàn): Colonial modernism in Vietnam, 1932-1941'. In Vietnamese, see Phan Cự Đệ, Tư Lực Văn Đoàn: con người và văn chương [The Self-Reliant Literary Group: People and literature] (Hanoi: Nhà xuất bản văn học, 1990). 
window onto Vietnam's experience of colonial modernity and tradition in the 1930s, the opportunities it opened, and the anxieties it evoked.

As this article shows, the production, consumption, and meaning of alcohol in Vietnam would be profoundly altered in the colonial period. One factor driving the changes was Vietnam's increasing integration in international markets and the availability of imported liquors like wine, champagne, and cognac, whether as objects of desire or consumption. Just as important, however, was the state's simultaneous attempt to monopolise the market for 'native' rice liquor and to limit imports of 'European' alcohol that together contributed to the explicit racialisation of alcohol and its consumption. The result was to make alcohol central both to the experience of a colonial modernity and to the concurrent configuration of a 'colonial tradition'. While imported wines and liquors would remain ideal symbols of modernity and markers of distinction, the reinvented traditions related to what the French called 'native' and the Vietnamese called 'our' alcohol would nevertheless become linked to evolving notions of community and nation that transcended rural-urban or popular-elite divisions and brought Vietnamese of all walks of life together in a shared experience of conviviality.

\section{The production of tradition}

Humans have been fermenting fruit and grains to make alcoholic beverages for millennia. ${ }^{23}$ Probably the earliest reference to alcohol in Vietnamese history is found in the story 'Họ Hồng Bàng' (The Hồng Bàng clan) in the fifteenth-century text Lĩnh Nam chích quái liệt truyện (Assorted tales of selected oddities from South of the Passes). It refers to the origins of the nation during the time of the Hùng kings, when 'the people lacked everything (and) had to use tree bark to make shirts, weave grass to make mats, use the essence of rice to make alcohol'. ${ }^{24}$ While the ancestors of today's Vietnamese may have been drinking undistilled beers and wines for thousands of years, distilling is a historically recent technology that was probably first used to make concentrated liquors in East and Southeast Asia starting around the $1300 s^{25}$ By the time the French began their slow conquest of Vietnam in 1858, distilling was a widespread practice that encompassed everything from villagers making liquor for family consumption to small factories. ${ }^{26}$

Early French accounts make it clear alcohol production in pre-colonial Vietnam had already undergone a degree of specialisation and industrialisation. Ethnic Chinese often played a central role in the trade, operating distilleries throughout Cochinchina in the south and in market towns and ports stretching along the Vietnamese coast as

23 Patrick McGovern et al., 'Fermented beverages of pre- and proto-historic China', Proceedings of the National Academy of Sciences 101, 51 (2004): 17593-8.

24 Quoted in Vũ Ngọc Khánh, Văn hoá Việt Nam [Vietnamese culture] (Hanoi: Nhà xuất bản văn hoá-thông tin, 2004), p. 503.

25 In China, possible references to distilled alcoholic beverages can be found in a variety of texts from the Tang and Song dynasties (7th to 13th centuries); however, later Ming historians, for example, Li Shizhen in his famous Compendium of Materia Medica, traced the invention of distilled alcohol to the Yuan dynasty (14th century).

26 Antoine Brébion, Une distillerie Indo-chinoise (Chalon-sur-Saone: Imprimerie Administrative K. Bertrand, 1909). See also Albert Calmette, 'Part 3: Distillerie indigène', in 'La fabrication des alcools de riz en Extrême-Orient' (1892), VNA1 RST 14165. 
far north as Hải Phòng. In the 1880s, for example, the distillery at Cần Giuộc in the Mekong Delta was run by a heterogeneous mix of twelve Hokkien, five Hakka, two Cantonese, and one Teochew Chinese. ${ }^{27}$ In Saigon at roughly the same period, the city's largest distillery featured 20 stills capable of producing 600 litres of liquor per day. ${ }^{28}$ In the north, concentration had taken a different path, resulting in 'distilling villages' that brought together multiple families, each operating one or more stills. In some cases, one village might specialise in growing sticky rice, while a neighbouring village - often with poor rice fields - transformed the rice into alcohol. ${ }^{29}$ Specialisation could also extend to related industries, with a village known for the quality of its alcohol sited next to a village producing pottery or ceramic flasks. ${ }^{30}$ In 1884 on the eve of the establishment of the French protectorate over Tonkin, there were just over 400 distilleries large enough to have come to the attention of Nguyễn tax collectors. ${ }^{31}$ Nevertheless, the rudimentary transportation infrastructure, the partially monetised economy, and the simple technologies involved all conspired to limit the penetration of the commercial alcohol market, and to ensure small-scale distilling remained the norm in the pre-colonial Vietnamese countryside. ${ }^{32}$

Small-scale distilling fit easily within the household economy, with families producing liquor for their own consumption, for their extended family, or for sale to neighbours or at a nearby market. For many families, distillation was a secondary occupation they undertook in addition to rice farming. It was a means to use up surplus rice, and to generate a product that could be used for exchange or sale. The spent mash left over after distilling (bồng rượu or bã rượu) was also a precious source of feed for pigs, and colonial officials calculated that pigs, rather than liquor, were the main source of income for small distillers. ${ }^{33}$ The Vietnamese term for making liquor - nấu (to cook) - underlines how intimately connected rươ was to the kitchen and to the hearth. The utensils for 'cooking' liquor could found in any household: a chõ for steaming the rice, a nồ (pot) for heating the fermented mash, and a cháo (frying pan) to condense the alcohol vapours. Making liquor was physically undemanding:

27 'Liste nominative des chinois employées à la distillerie de Cangioc', VNA2 Goucoch IB 38/084.

28 Calmette, 'Part 3: Distillerie indigène'.

29 See, for example, the village of Phú Lộc in Hải Dương province; Resident Bouchet to Resident Superior Tonkin, Hải Dương, 21 Sept. 1927, VNA1 RST 74799.

30 For descriptions of specialisation and integration with other industries, see Resident Quennec to Resident Superior Tonkin, Bắc Giang, 27 Apr. 1908, or Resident Gueroult to Resident Superior Tonkin, Hoà Bình, 20 Oct. 1915, VNA1 RST 74689.

31 René Monier, La Question du monopole de l'alcool au Tonkin et dans le Nord-Annam: contribution à l'histoire financière de l'Indochine (Paris: Emile Larose, 1914), p. 18.

32 Peters overstates the degree of industrialisation in pre-modern Vietnam, citing French officials and commentators writing in the early 1900 s to justify maintaining the French monopoly on liquor production in place since 1897. The colonial commentators argued that because alcohol production in northern Vietnam had already been industrialised, maintaining the monopoly would not cause any fundamental changes in Vietnamese economy or society. Erica J. Peters, 'Taste, taxes, and technologies: Industrializing rice alcohol in northern Vietnam, 1902-1913', French Historical Studies 27, 3 (2004): 569-600. For an illustration of how policy imperatives could transform officials' judgement, compare the radically different opinions expressed in: Monthly report, Resident Simoni to Resident Superior Tonkin, Bắc Giang, Mar. 1899, VNA1 RST 74789; and Resident Superior Tonkin Simoni to Governor General, Hanoi, undated (probably Jan./Feb. 1912), VNA1 RST 20978.

33 Monthly report, Resident Simoni to Resident Superior Tonkin, Bắc Giang, Mar. 1899, VNA1 RST 74789 . 
children, the elderly, and above all women could tend a still while seeing to other household tasks such as preparing meals. Just as they played a central role in the small-scale production of alcohol, women also played an important role in its sale, a fact that reflected their place in commerce more generally. ${ }^{34}$ These patterns persist to this day. The owner of a successful liquor shop in Hanoi described to me how her grandmother, mother, aunts, and sisters had begun to teach her the tasks involved in cooking ruơuu as soon as she was old enough to help around the home. At the age of 15 she was distilling her own liquor; she opened her own shop at the age of 26 when she realised that the profit margin in retail was far greater than in production. ${ }^{35}$

Ideally, distillers would make their liquor during the cold months when the air and water were relatively free from contaminating microorganisms and when cooler temperatures favoured more efficient fermentation. A figure in Antoine Brébion's 1909 Une distillerie Indo-chinoise shows the equipment used in a commercial distillery in Cochinchina at the turn of the century. ${ }^{36}$ The still consisted of three parts: the iron pot (usually a nồi ba mươi, or a pot for cooking 30 portions of rice), mortared into the furnace, in which the alcoholic liquid was heated; the cone-shaped 'belly', made out of slats of wood held together by iron bands, and which served to contain the vapours rising from the pot below; and on top, an amphora-shaped 'hat' made out of glazed earthenware that served to concentrate and then cool the alcohol vapours. The different parts of the apparatus were mortared together using a glaze made from clay and the distillation residue. The top of the 'hat' was hollowed out in order to contain 200$300 \mathrm{ml}$ of water. The water cooled the top of the hat, causing the alcohol to condense and drip into a hollow bamboo pipe inserted into the centre of the hat at a 45-degree angle. From there, the liquid would drip down the pipe and into tin or iron 20-litre jars partially immersed in water. The ruơ u that dripped slowly out of the bamboo condensing pipe would average around 30 to 40 per cent alcohol by volume. ${ }^{37}$

In a pinch, the freshly distilled liquor could be consumed immediately. However, most of it was placed in glazed earthenware containers (chum ruơ u) of up to 250 litres and aged for at least one month in a cool and humid environment, usually underground. This ageing process helps remove toxins, minimising the headaches that otherwise follow heavy drinking. Even after ageing, alcohol that has only been distilled once will contain sediment. This sediment will settle if the liquor is filtered or bottled and allowed to sit. Sometimes distillers would distil their ruơ u a second time to produce a higher quality, almost perfectly transparent, liquor. Some of the alcohol produced might be infused with flavouring agents: for example, apricot, lotus flowers, rose petals, chamomile, jasmine, or herbal remedies (thuốc bắc). ${ }^{38}$ Infused rượu was usually the purview of individual vendors or doctors, each with their own specialised

34 See, for example, the frequent prosecutions involving women that occurred after the French began requiring alcohol vendors to purchase licences, VNA2 P.5 IB.25/181.

35 Interview, Trịnh Út Anh, Hanoi, Jan. 2006.

36 Brébion, Une distillerie Indo-chinoise.

37 Jacques Mordaing, Le monopole des alcools indigènes au Tonkin et dans le nord-Annam (Hanoi and Hải Phòng: IDEO, 1913), p. 3. Calmette reports that Vietnamese in Cochinchina never drank spirits of less than 34 or more than 42 per cent alcohol by volume. Calmette, 'Part 3: Distillerie indigène'.

38 Phan Kế Bính, Việt Nam Phong Tục [Vietnamese customs] (Saigon: Nhà sách Khai trí, 1973 [191314]), p. 385. See also Nguyễn Văn Huyên, La civilisation ancienne du Việt Nam (Hanoi: Nhà xuất bản thế giới, 1994), p. 217. 
recipes. However, like double-distilled liquor, infused rượu was a more expensive product, intended either for special occasions or for use by the elderly as medicine. As a result, most of the alcohol consumed was clear or 'white' liquor (rượu trắng).

Rươu that was ready for consumption was sold and stored in bầu or be rượu, originally hollowed-out gourds, but more frequently made from glazed earthenware (sành). Whatever the shape and size, bottles of riợu were sealed with corks made of compressed dried banana leaves. For those who could afford it, rice liquor was a part of everyday life in Vietnam. In 1913, Phan Kế Bính wrote that alcohol consumption was common in the countryside, describing how some men could drink an entire bottle in a single draught, while others drank continually throughout the day. A 2004 work listed the seven traditional staples of Vietnamese cuisine as 'rice, fish, meat, leafy vegetables, sweet rice porridge, tea, and liquor' ${ }^{39}$ Most tellingly, a way of saying a meal is over and the guests have eaten their fill literally means: 'rice [and] liquor, full [and] drunk'. ${ }^{40}$ And in the much-loved classic of Vietnamese literature, the Tale of Kieu, alcohol is central to Nguyễn Du's evocation of an idyllic life: at the end of the epic poem, its star-crossed lovers spend their time 'now sipping liquor, now playing chess, now admiring flowers, now waiting for the rising moon'. ${ }^{41}$

Rice liquor is also an important part of rituals and ceremonies, such as those held during the New Year, weddings, and death anniversaries. The fifteenth-century Hồng Đức code contained a list of the gifts the groom had to present to the bride's family during the engagement ceremony (đám hỏi). Rượu figured prominently, with grooms required to present the bride's family eight to ten jugs, depending on their station. If practices in the nineteenth century did not follow the code strictly, alcohol still featured in the ritual exchanges of gifts between the two families, as well as the wedding processions to the bride's house (đám cươi), and to the groom's house (đuia dâu). Aside from being consumed by guests at the wedding meal, the liquor was also used ritually as an offering on the altars of the families of the bride and groom, and as part of the exchange of the marriage cup between bride and groom on the marriage night (hợp cẩn). Ceremonies such as those during the New Year (Tết), Summer Solstice (Tết Đoan ngọ), and ancestral death anniversaries (ky nhật or ngày giỗ) all featured the ritual offering and consumption of alcohol.

Rươ was an important part of medicine. Moderate drinking was seen as good for the health, and doctors recommended patients take three cups of liquor every evening. ${ }^{42}$ Ruơ $u$ was infused with a variety of herbs, leaves, roots, insects, and animal parts to produce traditional medicines. Different infusions could be used to prevent or treat different ailments, reflecting medical practices refined over thousands of years. ${ }^{43}$ For

39 Vũ Ngọc Khánh, Văn hoá Việt Nam, p. 541.

40 'Cơm rượu no say rồi'.

41 'Khi chén rượu, khi cuộc cờ. Khi xem hoa nở khi chờ trăng lên'; Nguyễn Du, The tale of Kiều, trans. Huỳnh Sanh Thồng (New Haven: Yale University Press, 1983), 11. 3223-4.

42 Lãn Ông, the eighteenth-century scholar and physician portrayed as the father of Vietnamese medicine wrote, 'Bán dạ tam bôi tửu, lương y bất đáo gia' [roughly, 'Three cups of liquor at midnight keeps the doctor away']. The saying is also common in Chinese medical works. Quoted in Thái Lương, Văn hoá rượu [Alcohol culture] (Hanoi: Nhà xuất bản Văn hoá-Thông tin, 1999), p. 6.

43 For a discussion of the history and uses of medicinal rượu, see Phan Văn Chiêu, Nhũng bài thuốc rượu phòng và trị bệnh [Prescriptions of medicinal liquor to prevent and treat disease] (Huê:: Nhà xuất bản Thoận Hoá, 1999). 
example, poisons were seen as an effective tonic, thus alcohol infused with poisonous snakes or insects might be prescribed for a lack of energy. Bile, particularly bear bile, was thought to improve the function of the liver and other internal organs. These animals or animal products might be infused alone or with medicinal ingredients such as ginseng. According to Phan Kế Bính, the most highly prized liquor was infused with ginseng and budding antler (rượu sâm nhung). Others were infused with a broad range of medicinal ingredients. One famous recipe, featuring almost thirty different types of herbs and medicines, was developed by doctors to help the emperor Minh Mang with the duties associated with his hundreds of concubines.

As Minh Mang's special recipe implies, gender shaped the consumption of alcohol in complex ways. Confucian feminine ideals that stressed modesty and propriety provided little space for the consumption of alcohol. Yet, particularly in the countryside, where elite culture confronted everyday practices, ideals and reality did not always conform. ${ }^{44}$ Early proponents of the colonial alcohol monopoly highlighted the way alcohol was consumed by everyone, men and women, young and old alike. ${ }^{45}$ Nevertheless, on the whole gender norms acted to limit how, when, and where women might drink, and to ensure that the public consumption of alcohol remained a largely male activity. One saying holds 'a man without ruơou is like a flag without wind'. ${ }^{46}$ As a result, liquor has come to be associated with all the major male rites of passage. One reference book lists four 'types' of ru'ơu: farewell (rượu tiễn biệt), friendship (rượu bằng hüu), swearing an oath (rượu thề nguyền), and going into battle (rượu chiến đấu) ${ }^{47}$ Even more important, however, was the generalised association of alcohol consumption with male sociability and conviviality. ${ }^{48}$ The nineteenth-century scholar and poet Nguyễn Khuyến expressed it most famously when he wrote: 'Good ruợu, without a kind friend, shouldn't be bought; not because of a lack of money, but because it shouldn't.'49

There is an expression in Vietnamese that 'good alcohol doesn't mind a terracotta flask', meaning that with wine as with people, it's what's on the inside that counts. ${ }^{50}$ Thus drinking utensils were usually simple: flasks made out of hollowed gourds or glazed earthenware, bowls or cups made out of glazed earthenware or, more rarely, china. From smallest to largest, different sizes of cups included chén hat mit (the

44 For an account of Vietnam's engagement with Confucian thought, see Shawn McHale, 'Mapping a Vietnamese Confucian past and its transition to modernity', in Rethinking Confucianism: Past and present in China, Japan, Korea, and Vietnam, ed. Benjamin A. Elman et al. (Los Angeles: UCLA Asia Pacific Monographs, 2002), especially pp. 400-410. On the gulf that separated Confucian ideals from the social reality of the village, see Dang Phuong-Nghi, Les Institutions publiques du Viet-Nam au XVII siècle (Paris: École Française d'Extrême-Orient, 1969), p. 35.

45 Calmette wrote 'In Cochinchina, the poorest Vietnamese and the most miserable Chinese coolie takes in an average of two and a half to three litres of spirits per month; the rich drink about 10 litres, nor do women deny themselves any more than they deny themselves tobacco and betel.' Albert Calmette, 'De quelques industries de Cochinchine et des perfectionnements scientifiques à y introduire', Bulletin de la Société de géographie commerciale de Paris 16 (1894-95): 89.

46 'Nam vô tửu nhu' cờ vô phong'.

47 Vũ Ngọc Khánh, Văn hoá Việt Nam, p. 530.

48 One saying - 'Trà tam tủu tủ - holds that for tea, one needs at least three drinkers, and for rượu, at least four.

49 'Rượu ngon, không có bạn hiền; không mua, không,phải, không tiền, không mua'.

50 'Rượu ngon chẳng quản be sành', or 'Rượu ngon bât luận be sành'. 
smallest, the size of a jackfruit seed), chén măt trâu (slightly larger, sized and shaped like the eye of a buffalo), chén vại (medium-sized), and bát or tô (small bowls). Drinkers would take their places around a bamboo mat spread on the floor or a bed, with the liquor, cups, and a few plates of food or condiments placed in the centre of the mat. If the host was wealthy and in a mood to celebrate, he might serve dog meat or other delicacies. More typical accompaniments were acidic fruits that varied according to the season and whatever was available in the host's garden: banana, guava, starfruit, mango, cluster figs (quả sung), and salted baby eggplant (quả cà muối), eaten green or pickled to cut the heat of the alcohol.

Drinking liquor did not involve expensive foods or elaborate rituals. Nevertheless, it did integrate various markers of respect for age and of mutual respect. When taking their places around the bamboo mat, older men generally sat 'inside' and younger men 'outside'. Younger men would take their places first, but would remain kneeling until the older men had all sat down. In a context involving family, the youngest member of the host's family would have responsibility for serving (setting out food, cups, bowls, and chopsticks, filling the guests' cups), as would the youngest of a group of male friends. If the context was one involving a host and a guest, the host would pour for the guest first; after the first cup, the guest would repay the kindness by serving the host. There was no prohibition on filling one's own cup, the only requirement being that one filled one's own cup only after all the others were filled. Depending on the context, either the guest or the oldest person present would be invited to drink first. Previously, when most houses had floors of pounded earth, before raising his glass, the first man to drink would pour a small amount of ruơu on the ground to give thanks for the earth's generosity and to make a symbolic connection with departed ancestors. ${ }^{51}$ After this ritual offering, the drinker would raise the cup and take a small sip. Then after expressing his appreciation (and without setting down the cup), he would drink the rest of the cup down. The rest of the party could then drink. With the exception of the first sip, cups were emptied in one draught, and the empty cup placed upturned on the table.

If many of the customs associated with drinking reinforced distinctions of age and, to a lesser extent, class, liquor at the same time functioned to create bonds across these barriers. This can be seen in the course of a drinking session as postures become more relaxed, older men serve younger, and words flow more freely. One expression for longtime drinking companions captures the closeness that results by destabilising the pronoun pairs that normally encode distinctions based on age. ${ }^{52}$ Particularly in central and southern Vietnam, the feeling of closeness when men would di nhậu (roughly, 'go drinking') was enhanced through the use of a single cup that was passed around the circle of drinkers. After draining one's cup, the drinker would refill it before inviting the man beside them to drink. And wherever the drinking occurred - north, centre, or south - it was almost inevitably accompanied by a loud and boisterous

51 A. Bouinais and A. Paulus, L'Indo-Chine française contemporaine (Paris: Challamel Aîné, 1885), p. 239.

52 'Bạn chén chú chén anh'. Literally, 'Friends cup younger uncle cup older brother', or more accurately 'drinking buddies', it reflects the way close male friends may purposely mix two distinct pronoun pairs chú-cháu (younger uncle-nephew) and anh-em (older brother-younger brother) to collapse the social distance between speakers. 
conviviality. As the liquor flowed, laughter became louder, stories or jokes racier, and opinions more heated. Thus rươ u served as both social glue and safety valve, reinforcing social bonds and creating a space where men might express ideas or emotions more freely.

Women did sometimes enter this highly gendered space. Just as they were associated with the production and sale of alcohol, so were they associated with its serving. One saying holds that 'As long as there is sky, there is water, there are mountains; As long as there is a woman selling rươ'u, I'll be getting drunk. ${ }^{53}$ The association of women with the serving of alcohol reached its highest expression in the space of the nhà hát à đào ('singsong-girl bars'). These highly gendered spaces of alcoholic socialisation were a local expression of a tradition that includes everything from the Chinese teahouse (cha lou, 茶楼) to the Japanese geisha. In these bars, women would be called upon to sing, to pour drinks, and to sit with and make more or less flirtatious conversation with their clients. These different forms of intimacy stretched across a spectrum that included everything from highly paid professional performers to indentured sex workers. The protagonist of the Tale of Kieu agrees to an arranged marriage in order to purchase her father's freedom; only too late does she discover that she has been sold into service in a nhà hát ả đào. ${ }^{54}$

These systems of production and consumption of alcohol and the gender norms that they reflected would be profoundly altered during the period of colonial rule. Above all, they would be shaped by three factors. One was the availability of new consumer goods and the opportunities they offered for the creation of distinction and the expression of new class and gender identities. Another was the state's racialisation of alcohol through its attempt to monopolise the market for 'native alcohol' and tightly control the market for imported wines and liquors. And a final factor was the way reconfigured traditions of alcohol production and consumption came to serve as points of reference for an evolving national identity.

\section{Colonial modernity, colonial tradition}

Even before the beginning of French rule, their wines were finding an appreciative audience among Vietnam's ruling classes, who after all were not unlike their contemporary emperors, kings, nobles, and aspiring commoners around the world. ${ }^{55}$ It was the taste of Russian elites for imported French wines, after all, that helped make the fortune of the famous Veuve Clicquot champagne house in the nineteenth century. The establishment of French rule after 1858 only accelerated this process of integrating Vietnam within global markets. By 1895, a French customs official could remark with more than a little condescension that 'there does not exist a single indigenous official, no matter how minor or how insignificant his powers, who does not have at his home several bottles of "Cognac", "Amaro" or even of "Absinthe". ${ }^{56}$ By

53 'Còn trời còn nước còn non; còn cô bán rượu anh còn say suia'.

54 Nguyễn $\mathrm{Du}$, The tale of Kiều, ll 911-1384.

55 Jean-Baptiste Chaigneau, 'Memoire sur la Cochinchine', repr. in Bulletin des amis du vieux Hue (Hanoi: 1923), p. 279; Eugene Veuillot, Le Tonkin et la Cochinchine: le pays, l'histoire et les missions (Paris: Librarie Catholique, 1883), pp. 90, 243.

56 Claude Coqui, Director of Customs and Monopolies to Governor General, Hải Phòng, 23 Oct. 1895, VNA1 RST 74744. 
the turn of the century, champagne in particular had become a shorthand for the cultural transformation of the Vietnamese elite under colonial rule. The critic Trần Tế Xương, for example, used the image of officials drinking milk in the morning and champagne at night to underline the financial and cultural distance that separated them from their subjects. ${ }^{57}$ Three decades later, the cover of Phong Hoá would make the same point. In a cartoon entitled 'Two sirs work and make connections', two smiling bureaucrats in traditional dress sit at a dinner table, toasting their hard work with imported red wine. ${ }^{58}$

Yet even more than the association of France's alcohol with its collaborating elites, it was the state's alcohol monopoly that ensured alcohol would be a particularly politicised product in colonial Vietnam. ${ }^{59}$ The alcohol trade was the object of intense state interest and various forms of taxation from the earliest days of the French colony. Nevertheless, it was only after 1897 and the convergence of the state's increasing need for tax revenue with new technologies and an ambitious entrepreneur named A.R. Fontaine that Vietnam was graced with an effective monopoly over the production and sale of rice alcohol. Although the system varied over time and space, in general it operated to guarantee Fontaine anywhere from 69 to 100 per cent of the legal market for native alcohol in Vietnam. In practice, it consisted of Fontaine's huge factories in Hanoi, Hải Dương, Nam Định, and Bình Tây, and the Department of Customs and Monopolies that oversaw the systems of distribution and sales, 'encouraged' or forced Vietnamese to purchase the liquor, and attempted to drive illegal competitors from the market through invasive systems of surveillance and repression. Despite occasional attempts at reform, the system would survive essentially unchanged well past the death of Fontaine in 1934 until the end of the colonial period.

A series of cover illustrations from Phong Hoá confirms the political salience of the alcohol monopoly. ${ }^{60}$ One cover took its inspiration from the famous couplet quoted earlier, 'Now sipping liquor, now playing chess ...', from the Tale of Kiều, making subtle changes in wording to transform the original description of a pastoral ideal into an indictment of the harsh reality of colonial rule. ${ }^{61}$ In the first of four panels that make up the illustration, a villager tends to a small pot of riơu $u$, steaming on a fire. In the second, a native agent binds the unlucky villager to the flagpole outside the local Customs office. In the third, he labours in a colonial garden under the gaze of a prison guard. And in the final panel, he looks wistfully at the rising moon through the bars of his prison cell. An illustration from the leftist journal Ban dân (Friend of the people), published during a period of looser censorship laws following the election of the Popular Front government in France, was even more explicit as it

57 Trần Tế Xương, 'Cái chữ nho', in Les chefs d'oeuvre de la litterature vietnamienne, ed. Dương Đình Khuê (Saigon: Kim Lai ấn quán, 1966), p. 393.

58 Phong Hoá 157 (11 Oct. 1935): 1; http://issuu.com/nvthuvien/docs/ph_157_11_oct_1935? $\mathrm{e}=5818453 / 3052066$.

59 Sasges, 'State, enterprise, and the alcohol monopoly'.

60 The alcohol monopoly was the sole subject of ten cover illustrations during Phong Hoás print run (1932-36). By comparison, the opium monopoly was the sole subject once.

61 The satirical revision reads: 'Khi nấu rượu (lậu), khi cột cờ'. Khi xem hoa nở khi chờ trăng lên' ['Now sipping (contraband) liquor, now the flagstaff. Now admiring flowers, now waiting for the rising moon'], Phong Hoá 161 (8 Nov. 1935): 1. http://issuu.com/nvthuvien/docs/ph_161_08_nov_1935? $\mathrm{e}=5818453 / 3052072$. 
called attention to the issue of forced consumption. ${ }^{62}$ In it, an emaciated villager, dressed only in a loincloth, begs a village official's forgiveness because he does not have money to purchase his quota of factory alcohol. The official orders the villager to sell his loincloth to purchase the alcohol, failing which he would be thrown in prison.

Despite policies designed to encourage, if not force, alcohol consumption and the best efforts of Customs agents to interdict clandestine distilling, the combination of industrial capacity and state power probably captured less than half of the real alcohol market. ${ }^{63}$ Throughout Vietnam, villagers developed a variety of strategies to counter the threat of surveillance and continue distilling and drinking their own alcohol. As in the pre-colonial period, distillers ranged from the small and artisanal - like Oan and Phấn, two sisters from Bắc Ninh province convicted for possession of a few kilos of fermenting rice - to the industrial - as in the village of Hữu Tụ in Hà Đông province, where agents discovered a distillery with 220 litres of alcohol ready for sale and $11,000 \mathrm{~kg}$ of fermenting rice with a yield of about 7,500 litres. ${ }^{64}$

Rejecting the official binary of 'native alcohol' and 'European alcohol', Vietnamese instead posited three categories: rượu ta (roughly, 'our liquor'), rượu ty ('factory liquor'), and rượu tây ('Western liquor'). The unenthusiastic response of Vietnamese to the factory liquor ensured that contraband riơ $t a$ would continue to play a central role in ceremonies and socialisation. In 1908 a Customs agent and his companion found themselves being chased down a street by a dozen men brandishing staffs and machetes after they unwisely attempted a search for contraband alcohol in the home of a family observing a death anniversary. ${ }^{65}$ After disastrous experiences during the monopoly's first years of operation, the administration suspended all searches during Têt, allowing Vietnamese to distil and consume the alcohol that formed an integral part of the New Year celebrations. ${ }^{66}$ Regarding Têt, the Resident Superior of Tonkin wrote that 'the smallest incident ... could effectively degenerate into serious disorder' ${ }^{67}$ Nevertheless, driven by the need for tax revenue and encouraged by the shareholders in Fontaine's highly lucrative distilling business, the state persisted in its efforts to capture the market for 'native alcohol', at least outside of the annual holiday period.

One of the key claims the state advanced in its efforts to sell Fontaine's alcohol was its modernity. The state's backers regularly contrasted traditional distilleries, with their dirty pots bubbling away in bamboo shanties and cooling jars immersed in pools

62 Bạn dân, Hanoi, 8 May 1937.

63 One study estimated that 60 per cent of Vietnamese consumed contraband alcohol. Another estimated that the state alcohol monopoly supplied only about one-third of the total market. Bernard-Marcel Peyrouton, 'Etude sur les monopoles en Indochine', (Ph.D. diss., Université de Paris, 1913), p. 192; Henri Guermeur, Le régime fiscal de l'Indochine (Hanoi: IDEO, 1909), pp. 215, 224.

64 For Oan and Phấn see Resident Sestier to Resident Superior Tonkin, Bắc Ninh, 13 Apr. 1908, VNA1 RST 74738. For Hữu Tụ, see Director of Customs and Monopolies Kircher to Resident Superior Tonkin, Hanoi, 8 June 1915, VNA1 RST 74799.

65 Statement of Agent Mahé, Sơn Tây, 16 Jan. 1908, VNA1 RST 74760.

66 In 1911, the administration reminded agents to suspend activities during Têt 'following the practices of previous years'. Director General Customs and Monopolies to Under-Directors, Hanoi, 20 Jan. 1911, VNA1 RST 74801.

67 Resident Superior to Director General Customs and Monopolies, Hanoi, 8 Feb. 1912, VNA1 RST 74737. 
of fetid water, all of it under swarms of buzzing flies, with the perfect asepsis and scientific precision of Fontaine's gleaming assembly lines. Moreover, the factory alcohol was uniform in taste and alcohol content and its clarity attested to its apparent purity. The term the state used to describe Fontaine's strange hybrid - 'native alcohol produced by European methods' - underlines the uneasy balance they had to strike between 'tradition' and 'modernity'. But whatever their rhetorical success, the liquor left much to be desired. The continuous column stills Fontaine used in his factories produced almost pure ethanol, guaranteeing the liquor would be essentially tasteless. Even some French officials were sceptical. In the words of one, 'the alcohol is of the required degree, that is all that can be said'. ${ }^{6}$

One of the key markers of the factory liquor's modernity was its packaging. By law, liquor could only be sold to consumers in the bottles of the state alcohol monopoly, or Régie d'Alcool. Previously, smaller quantities of liquor had been stored and sold in earthenware bầu or be rươu, sealed with corks made of compressed dried banana leaves. By contrast, the Régie's bottles - at various times 750, 1000, and finally $650 \mathrm{ml}$ - were sealed with a crimp top and bereft of any mark save the letters 'RA' that also adorned the entrance to licensed retailers. ${ }^{69}$ One goal of using the standard clear glass bottles was to facilitate the interdiction of contraband, another was to underline the perfect limpidity of the new, modern liquor, and a third was to promote the growth of a fledgling - and French-owned - glass industry.

In practice, the results of the introduction of the new glass bottles were more complex. While the Régie intended consumers to return the bottles either for a refill or refund of their deposit, instead the bottles were quickly adopted by both producers and consumers of contraband liquor, who simply resealed them with the traditional dried banana leaf. The modern bottles provided a convenient standard measure and allowed consumers to know not only how much liquor a bottle contained, but also to judge its quality. The use of the term tăm rươ to denote liquor of the highest quality dates from the colonial period and the introduction of glass bottles. To test the quality of rice liquor, consumers would shake bottles vigorously, then observe the size and quantity of bubbles, or tăm, that would appear when the bottle was allowed to rest. The smaller the bubbles and the greater their number, the more delicious the liquor. Much like the ubiquitous Nestlé condensed milk can, the Régie d'Alcool's clear glass bottle with its rudimentary 'RA' trademark would be one of the most common - if unintended - ways in which ordinary Vietnamese consumed modernity.

Unlike the standardised factory alcohol, for many years available only in two variants of 35 and 40 per cent alcohol, ruợu ta offered consumers a range of choices. Alcohol content might range from a low of 20 per cent to a high of over 50 . Cheaper liquor might be made from ordinary rice ( $g a t^{\prime} e^{3}$ ) or even cassava, while more expensive liquor would be made from particular varieties of sticky rice (gạonếp) like the nếp cái hoa vàng renowned in Tonkin for its delicate perfume. These high quality contraband liquors often commanded higher prices than even the state's heavily taxed

68 Controller Ulmann to the Under-Director of Customs and Monopolies for Annam, Huế, 17 July 1907, FNOA INDO/GGI/8907.

69 There was also a short-lived experiment with $100 \mathrm{ml}$ bottles. For a pun on the Régie d'Alcool (RA) and the Vietnamese verb to go out $(r a)$, see the front page illustration of Phong Hoá 57, 28 July 1933; http://issuu.com/nvthuvien/docs/ph_057_28_jul_1933?e=5818453/3051846. 
alcohol. ${ }^{70}$ In Annam and Cochinchina, the 'us' implicit in 'our liquor' was gratifyingly inclusive, encompassing not just contraband but also the liquor produced in the few score independent distilleries that were allowed to operate alongside the statesupported hegemon, the Société française des distilleries de l'Indochine (SFDIC). ${ }^{71}$ Across Tonkin's northern borders, Chinese distilleries also engaged in a lively, if illegal, cross-border trade; a similar trade allowed Cambodian distillers to sell their liquor, renowned for the fragrance that resulted from the addition of palm syrup, on the Cochinchinese market. ${ }^{72}$ Yet whether produced legally or not, rươ ta in central and southern Vietnam was just as likely to be produced and sold by ethnic Chinese as by Viẹt. Over time, the state and the SFDIC responded at least minimally to consumers' demands for more choice. By 1935, the Governor of Cochinchina was able to proclaim that finally, 'even in the most distant towns, the administration offered consumers a range of liquors - vintage, factory, and rustic - suited to each and every taste' ${ }^{73}$ Yet despite the increased selection and reduced prices, contraband production remained endemic.

At the same time officials had defined 'native' alcohol, they had posited its 'European' other, which is to say everything else. The colonial state's regulation of these exotic products was shaped by a peculiar mixture of culture, economics, and racial politics. One factor was the cultural prejudice of French elites against distilled liquors. Another factor was powerful French viticulture lobbies and their effective deployment of a French 'tradition' of wine drinking. As a result, imported liquors like brandy, whisky, or gin were subject at different times to high excise duties, strict quotas, and even occasional outright bans. By contrast, beverages of less than 15 per cent alcohol were imported freely and subject to minimal duties. The strict regulation of the market for imported liquor served to promote the local production of 'European' liquors like the rum produced at the Mazet distillery in Saigon. At the same time, it turned imported liquors such as cognac or Scotch whisky into both expensive status symbols and frequent targets of counterfeiters. Yet the most important consequence was to shift consumption towards beverages with lower alcohol content. When Vietnamese consumed colonial modernity, it would usually be in the form of beer and wine, whether still, sparkling, or fortified. The outcome reflects both the transposition of French wine culture to Indochina and the colonial regime's racialisation of alcohol.

Some indication of how seriously the state took the racialisation of alcohol can be seen in 1927, when the state lifted an eight-year ban on the importation of European eaux de vie and instituted a system of quotas allocated to hotels, clubs, and bars in

70 Tournois, Mayor of Hải Phòng to Resident Superior, Hải Phòng, 7 Oct. 1915, VNA1 RST 74689.

71 See the 'Tay Chow Beng affair' and the imaginative and effective propaganda Chinese distillers deployed against the SFDIC and its factory alcohol. 'Procès colonial: Les dessous du monopole de l'alcool en Cochinchine', La Dépêche Coloniale, 19 Mar. 1906, FNOA FM/INDO/NF/4039.

72 For northern Vietnam see Vincent, Commandant of the First Military Territory to Resident Superior of Tonkin, Moncay, 4 Oct. 1915, VNA1 RST 74 689. For Cambodia see Mercadier, 'Mise en vente an Cochinchine des alcools fabriques au Cambodge et mis en vente au Cambodge des alcools produits en Cochinchine' (n.d., probably 1926), CNA RST 1489. In 1919 the laws were amended to allow the legal sale of Cambodian liquor in Cochinchina.

73 The terms used were 'alcools de cru, alcools d'usine, alcools de campagne'. Circular from Governor of Cochinchina, Saigon, 18 Mar. 1935, VNA2 Goucoch divers 3220. 
Indochina selling to a European clientele. ${ }^{74}$ The quotas were allocated by a fourperson committee composed of the Governor General or his representative, the Director of Customs, the Director's chef de cabinet, and the President of the Hanoi Chamber of Commerce. Demands were commonly rejected or revised downwards on the grounds that the establishment in question did not have a sufficient number of European clients. ${ }^{75}$ Moreover, officials were instructed to ensure that the liquor imported went directly to the establishment, and that the licences were not used by trading houses to import liquor beyond their own annual quotas and then sell it on the open market. ${ }^{76}$ Whatever the results may have been in practice, the colonial state clearly sought to limit the amount of 'European' liquor available to Vietnamese consumers. Nevertheless, imported wines and liquors remained available to those with the money and the taste to purchase them.

By positing this binary - indigenous/traditional and European/modern - the state turned imported alcoholic beverages into ideal markers of modernity and progress. Short stories and essays frequently referenced imported alcohol to underline class distinction. Particularly in the black-and-white illustrations and cartoons that accompanied these texts, alcohol served as an immediately recognisable symbol. 'Traditional' rice liquor was clear, stored in gourds or the simple Régie d'Alcool bottle, and consumed from small cups. By contrast, 'modern' products like beer and red wine were dark in colour and consumed from glasses. Champagne, with its distinctive bottle, cork, and accoutrements like coolers and coupe glasses, was another ideal symbol of the new forms of consumption and leisure aspired to by wealthy and not-so-wealthy urban Vietnamese, both women and men.

A short story from 1936 by Đoàn Phú Tứ, 'Sau cuộc khiêu vũ' (After the dance) revolves around two young male friends, Minh and Sâm, and the woman Xuyến who saves Minh from committing suicide. ${ }^{77}$ In Minh's melodramatic plan, he would get drunk on champagne, take poison, and then die in the arms of one of the beautiful women who frequented Hanoi's exclusive dancing clubs. The story is littered with references to the characters' wealth, class, and avid participation in a global cosmopolitanism. Minh and Sâm wear 'smoking' (tuxedos) and dine at the Hotel Royal. In his suicide note, Minh leaves his Ford car to his friend Sâm and his Japanese dog to Xuyến, whom he only just met. The lovely young woman lives independently in a 'garçonnière' apartment, dances the 'foxtrot' and the 'Boston' at the Mikado nightclub every night, and wraps herself in a kimono when the two men arrive unexpectedly at her apartment. Alcohol features not only in the text, but also in the illustrations that accompany the story. In the background of one, elegant couples, the men in dinner jackets and the women in modern áo dài, sway to unheard music. In the foreground,

74 Governor General of Indochina, Executive Order of 8 July 1919; Executive Order of 9 July 1927.

75 See, for example, Resident Superior to Governor General, Hanoi, 16 Mar. 1934, FNOA INDO/GGI/45484.

76 Acting Governor General to Residents Superior and Governor of Cochinchina, Hanoi, 5 Mar. 1931, FNOA INDO/GGI/45484.

77 The story appeared in two parts: Phong Hoá 183 (17 Apr. 1936): 12-13; Phong Hoá 184 (24 Apr. 1936): 10-14; http://issuu.com/nvthuvien/docs/ph_183_17_apr_1936; http://issuu.com/nvthuvien/docs/ph_184_24_apr_1936?e=5818453/2893112. 
a bottle of champagne chills in a cooler, a champagne coupe on either side. In another, a plate of fruit is juxtaposed with a bottle of wine. ${ }^{78}$

The short comic story 'Lý Toét ra mỏ' (Lý Toét visits the mine) underlines the role alcohol played in the crafting of distinction in colonial Vietnam. ${ }^{79}$ The story relates the series of linguistic and cultural misunderstandings that ensue when the bumbling scholar-official pays a New Year visit to his daughter Ba Vành and her European husband at the mine the latter manages. Ba Vành's husband mistakes Lý Toét for a rickshaw coolie, while the latter misunderstands the term 'coolie' as the honorific 'cu ly' (village mayor). When the husband attempts to shake Lý Toét's hand, the older man assumes he's offering to take the va-li (briefcase, from the French valise) he's carrying. Awkward introductions over, the jovial European invites everyone to drink, offering an array of liquors like 'rướu con mèo' (Dubonnet), 'dom' (DOM Benedictine), and 'cốt nhắt' (cognac) that the poor villager has never heard of. He feels relief when he hears the word 'xâm banh' (champagne), mistaking it for liquor infused with ginseng $(s \hat{a} m)$. When the bottle is duly produced, his daughter asks if he's ever tasted it before. Seeing the distinctive cork, Lý Toét replies that he's seen people drinking this curious 'banh' (bang) liquor earlier in the day at the station, where a stall keeper was selling bottles for four pennies each. When the top was removed, he explained, there was a sound like exploding fireworks. The husband and wife smile indulgently, knowing the old man in fact is referring to bottles of carbonated lemonade. Just then, the husband pops open the bottle of champagne with a loud report that Lý Toét takes for gunfire. Frightened out of his wits, he runs from the house, calling for help to repulse the presumed bandit attack.

Alcohol consumption was a means for young urbanites of means to assert a cultural superiority. Yet it also reflected the unease they felt when confronted with traditional drinking cultures, and its uncivilised, even unruly conviviality. This unease can be seen in many of the cartoons featuring the bumbling villager, Lý Toét. ${ }^{80}$ In these cartoons where he is portrayed drinking and/or drunk, he clearly resembles a thằng bờm rượu (drunken idiot), a character with a long history in Vietnamese folk tales. ${ }^{81}$ In one cartoon, Lý Toét's drinking companion Xã Xệ asks why he always drinks four cups of liquor when his doctor told him to only drink two. Lý Toét replies that he went to see two doctors, both of whom told him the same thing. ${ }^{82}$ The effect was

78 Phong Hoá 184 (24 Apr. 1936): 10-11.

79 Phong Hoá 85 (11 Feb. 1934): 18; http://issuu.com/nvthuvien/docs/ph_085_11_feb_1934muaxuan? $\mathrm{e}=5818453 / 3051961$.

80 For examples of Lý Toét and traditional drinking culture, see Phong Hoá 170 (10 Jan. 1936): 3; or Phong Hoá 178 (13 Mar. 1936): 3. For an obviously drunk Lý Toét, see Phong Hoá 72 (10 Nov. 1933): 5; Phong Hoá 184 (24 Apr. 1936): 9 or Phong Hoá, 185 (1 May 1936): 5; http://issuu.com/nvthuvien/docs/ph_170_10_jan_1936? e=5818453/3052089; http://issuu.com/nvthuvien/docs/ph_178_13_ mar_1936? $=5818453 / 3052105 ; \quad$ http://issuu.com/nvthuvien/docs/ph_072_10_nov_1933? e=5818453/ 3051943; http://issuu.com/nvthuvien/docs/ph_184_24_apr_1936?e=5818453/2893112; http://issuu. com/nvthuvien/docs/ph_185_01_may_1936? $=5818453 / 2893113$.

81 The drunken idiot might serve variously as comic relief, as an unwitting foil to a nefarious plot, or as the subject of a morality play. For an example of the latter, see Xuân Quang, 'Anh Nông Dân hay rượu' [The village tippler], in Tập Truyện Cổ Tích [Collected fairy tales] (Hanoi: Nhà xuất bản Phồ thông, 1957): 33-9.

82 Phong Hoá 149 (17 May 1935): 3; http://issuu.com/nvthuvien/docs/ph_149_17_may_1935? $\mathrm{e}=5818453 / 3212460$. 
to make an explicit link between drinking and behaviours that had now come to be seen not just as uncivilised, but even potentially threatening to a modern and sanitised order. This linkage was made particularly clear in a cartoon depicting the two characters happily ordering another plate of dog meat and pickled cabbage to go with their liquor. In the background, hangs a dog carcass and entrails, gruesomely displayed in a glass case. ${ }^{83}$

Gender was intimately tied to the issue of alcohol consumption and its relation to the evolving construction of modernity and tradition. The pages of Vietnam's leading women's journal, Phư nũ tân văn (Women's News) in addition to advertisements for clothes, makeup, perfume, bicycles and cars, also saw ads for Adet and Bisquit cognacs, Mana rum, De Jean liqueur, Quina Gentiane fortified wine, Hautes Côtes red wine, and Marquis de Bergey champagne, to name just a few. The frequent ads for alcohol in Phu nũ tân văn demonstrate the new consumption opportunities available to affluent Vietnamese women. Yet they also hint at the way consumption practices were deployed in the construction of new identities. Xuyến wasn't the only female character to live independently and engage in a global cosmopolitanism. In an illustration to accompany the serialisation of Nhât Linh's story 'Đoạn tuyệt' (The rupture), two new women discuss the trials of romantic love over glasses of wine. ${ }^{84}$ In the story 'Đời mưa gió' (Tempestuous life) by Khái Hưng and Nhất Linh, the female protagonist Tuyết proves a stronger drinker of wine than her husband. As Chương lies asleep at the table, drunk after their meal together, she calmly composes a letter to her lover Bảo to break off their affair. ${ }^{85}$

While the consumption of wine and champagne by characters like Xuyến and Tuyết served to mark their independence and modernity, rice liquor by contrast came to symbolise the subjugation they sought to escape. One cartoon was titled: 'Vietnamese women: once having married, they must shoulder the burden of their husbands' assets.' 86 The picture depicts a woman in traditional dress, carrying two baskets slung from a shoulder pole. Among her husband's meagre assets are an ancestral stele, a teapot, an opium pipe, and three bottles of liquor. Another cartoon, however, illustrated the anxiety some felt at the prospect that new women and their supporters might succeed too well in their battle for women's rights. In 1933, Phong Hoá featured a cartoon entitled 'But now roles and ranks have changed'.87 In the first panel, subtitled 'In the past', a wife bears her husband on her back, his long fingernails, pouch of poetry and bottle of liquor marking him as a scholar and a man of leisure. In the second, subtitled 'Today', the roles are reversed: a young husband, smartly attired in Western dress, carries his wife on his back.

83 Phong Hoá 189 (29 May 1936): 15; http://issuu.com/nvthuvien/docs/ph_189_29_may_1936? $\mathrm{e}=5818453 / 2893118$.

84 Phong Hoá 145 (19 Apr. 1935): 11; http://issuu.com/nvthuvien/docs/ph_145_19_apr_1935? $\mathrm{e}=5818453 / 3212454$.

85 Phong Hoá 98 (18 May 1934), 13; http://issuu.com/nvthuvien/docs/ph_098_18_may_1934? $\mathrm{e}=5818453 / 3212465$.

86 Phong Hoá 36 (3 Mar. 1933): 3; http://issuu.com/nvthuvien/docs/ph_036_03_mar_1933? $\mathrm{e}=5818453 / 3051802$.

87 The title is taken from line 959 of the Tale of Kieu. Phong Hoa 35 (24 Feb. 1933): 11; http://issuu. com/nvthuvien/docs/ph_035_24_feb_1933?e=5818453/3051800. 
Instead of poetry and liquor, she is depicted with new markers of leisure and consumption: bareheaded, coiffed in the European style and wearing a modern áo dài, she applies powder to her face, oblivious to the exertions of her husband below.

It wasn't just the drunken villager or the new woman who caused anxiety. The consumption of European alcohol was symbolic of larger changes in social relations. Drinkers of imported beverages were often portrayed in pairs, or even alone, revealing how the consumption of European alcohol could undermine drinking's important social function. ${ }^{88}$ While Lý Toét is usually shown eating and drinking rice liquor with friends, in a cartoon entitled 'Lý Toét eats a Western meal to ring in the New Year', he sits alone at a table with food and wine spread before him, unable to eat for lack of a rice bowl. ${ }^{89}$ Most unsettling, however, was the breaking down of clear social roles. In 1930s Vietnam, where age no longer carried the same emotive weight and wealth trumped social position, it was no longer clear who was the host and who was the guest. In one cartoon, two men in European dress sit at a table, two bottles of beer before them. One asks the other how much he can drink; the reply: it depends on which one of us is paying. ${ }^{90}$ In another, one friend drinks wine greedily straight from the bottle. His companion asks: 'Why don't you leave a little something for me?' The reply: 'Okay, I'll leave you to pay the bill.' ${ }^{\text {'1 }}$ As the cartoons suggests, social relations were in flux. And if it was unsure who would in the end pay the price, it was clear that until the bill came everyone would seek to use the fluid situation to his or her own ends.

One response was to posit a different kind of modernity that rejected aspects of this new consumer culture and instead embraced sobriety and self-control. Vietnamese culture, much like that of China, had long associated liquor with literary culture. ${ }^{92}$ In Vietnam of the 1920s and 30s, that tradition was embodied in the poet Nguyễn Khắc Hiếu (pen name Tản Đà), who made liquor and drinking the theme of much of his poetry. Some intellectuals criticised the older poet, in part because of his debt to an older tradition of poetry, but more importantly for his lack of creativity, the way he recycled outdated literary tropes, and the way he seemed to mistake alcoholic for more genuine forms of poetic inspiration. In one cartoon entitled 'Nguyễn Khắc Hiếu with his life's work', the poet is depicted surrounded by empty liquor bottles, a pen in one hand and a cup in the other as he raises it unsteadily to his lips. ${ }^{93} \mathrm{In}$ another, entitled 'Nguyễn Khắc Hiếu teaches literature', the obviously drunk poet

88 For example, see the image of a solitary diner in Phong Hoá 73 (17 Nov. 1933): 7; http://issuu. com/nvthuvien/docs/ph_073_17_nov_1933?e=5818453/3051944.

89 Phong Hoá 86 (23 Feb. 1934): 6; http://issuu.com/nvthuvien/docs/ph_086_23_feb_1934? $\mathrm{e}=5818453 / 3051963$.

90 Phong Hoá 185 (1 May 1936): 7; http://issuu.com/nvthuvien/docs/ph_185_01_may_1936? $\mathrm{e}=5818453 / 2893113$.

91 Phong Hoá 52 (23 June 1933): 8; http://issuu.com/nvthuvien/docs/ph_052_23_jun_1933? $\mathrm{e}=5818453 / 3051843$.

92 In the poem 'Thơ Say', Nguyễn Khuyến tells aspiring poets who want to study his poetry that the first requirement is 'three hundred upturned cups beside an empty flask'. Quoted in Hoa với rượu: Tập thơ [Flowers with liquor: A collection of poetry], ed. Ngô Văn Phú and Nguyễn Đức Quang (Hanoi: Nhà xuất bản Hội nhà văn, 1996), p. 16.

93 Phong Hoá 14 (22 Sept. 1932): 5; http://issuu.com/nvthuvien/docs/ph_014_22_sep_1932? $\mathrm{e}=5818453 / 2874154$. 
raises a cup to his audience and informs them: 'You want to ask me how to write poetry? Easy: liquor in, poetry out!' 94

The lampooning of Nguyễn Khắc Hiếu reflected the belief by some that alcohol consumption impeded clear thinking and made possible an escapism incompatible with their efforts to reform colonial society. In one cartoon, two friends sit at a table drinking red wine. Despite the fact they're already drunk enough to mistake the single bottle on the table for two, nevertheless one of the pair points out that if only they drink more, the two bottles will turn into four. ${ }^{95}$ The linkage between temperance and a sober, vigorous modernity was made particularly clear on the cover of the 17 November 1933 issue of Phong Hoá. ${ }^{96}$ One half of the cover consisted of an image formed of a line of text spiralling gradually inwards. The text reads:

Alcohol is a poison. All of you must know this already. I respectfully give this advice, from now on all of you stop drinking alcohol, drinking alcohol is injurious, if you stop drinking alcohol you'll understand immediately ... what's more, if you drink, drinking wastes money and makes you mindless, obscures your intellect as if you were crazy and mad.

The other half of the cover was devoted to a manifesto entitled 'Love life' (Yêu đời) and written by Khái Hưng (pen name Nhị Linh). The text is an exposition of the Tự Lực Văn Đoàn group’s evolving philosophy. While it admitted that there was much in life that was ugly and tragic, yet still 'as long as one is alive, then one must strive to make life better and easier. Believing in oneself, believing in life was the way to give life meaning.'

By placing the two - one call for sobriety and another call to 'love life' - together on the same page, the editors underlined the way temperance could form part of a commitment to confront life and all its problems, and bring to bear upon those problems the full force of their vision and intellect. In many ways they were taking up the sorts of arguments and images advanced by temperance and prohibition advocates in places like Europe and the United States. Yet transposed to Vietnam, the arguments lost their basis in Christian morality and instead reflected the politics of opposition to colonial exploitation and the conception of a vigorous, sober, self-reliant modernity whose energy risked being sapped by the seduction of drink. Temperance would allow Vietnamese - or at least certain members of the intelligentsia - to avoid being implicated in the state's abusive alcohol monopoly while simultaneously resisting the temptations of new forms of consumption. Instead of wasting their energies on drink or the pursuit of consumer goods, Vietnamese might instead turn them to projects like the Tự Lực Văn Đoàn’s ‘Đoàn Ánh Sáng' (League of Light) urban reform project. ${ }^{97}$

\footnotetext{
94 Phong Hoá 21 (11 Nov. 1932): 4; http://issuu.com/nvthuvien/docs/ph_021_11_nov_1932? $\mathrm{e}=5818453 / 3212417$.

95 Phong Hoá 53 (30 June 1933): 3; http://issuu.com/nvthuvien/docs/ph_053_30_jun_1933? $\mathrm{e}=5818453 / 2827766$.

96 Phong Hoá 73 (17 Nov. 1933): 1; http://issuu.com/nvthuvien/docs/ph_073_17_nov_1933? $\mathrm{e}=5818453 / 3051944$.

97 Martina Nguyen, 'The state in microcosm: The League of Light [Đoàn Ánh Sáng] and housing reform in Hanoi, 1937-1941', paper presented at the workshop, 'The state in Vietnam and the state of Vietnamese studies', Harvard University, 24-26 Apr. 2015.
} 
It is not clear how much purchase this advocacy of temperance had. Even leading figures of the Tự Lực Văn Đoàn like Nhất Linh or Khái Hưng were well-known drinkers and enthusiastic participants in the demi-monde of late colonial Hanoi. The expanding economy allowed the culture of the nhà hát ả đào to reach new heights in the colonial period. In Hanoi they were found in Vạn Thái, Ngã Tư Sở, and above all Khâm Thiên districts. They combined in varying proportions elements of singing house, bar, and brothel, and catered to every market segment, from workers to high officials. They normally had two floors: a public first floor where the more talented $a$ đào might perform, and a second floor divided into rooms where clients might arrange private parties of singing (chầu hát), drinking (chầu rượu), or both. Some ả đào could become well-known performers and capitalise on opportunities to participate in increasingly global markets for entertainment. Đàm Mộng Hoàn, for example, won a recording contract with Pathé, and sold records in Indochina, Hong Kong, and France. ${ }^{98}$ Yet for most à đào, their world and aspirations were more limited. Instead, they provided services in spaces of male sociability, facilitating forms of exchange and conviviality with roots far back into the pre-colonial period.

Different factors conditioned the resilience of traditional drinking cultures. One was the deep link between drinking and conviviality. While new Western wines and liquors may have been superb markers of distinction and of evolving gender identities, their expense and their very different drinking rituals made them unsuited to facilitating sociability and conviviality. Yet even more important was the state's alcohol monopoly and the way it had configured the market for alcohol into three segments: 'our liquor', 'factory liquor', and 'European liquor'. For Vietnamese, drinking 'our liquor' was a means to assert an indigenous identity while at the same time symbolically opposing one of the colonial regime's most hated institutions. The cumulative effect was to ensure that elite calls for a culture of sobriety and self-restraint were stillborn, and this was to link elite and popular drinking cultures in important ways. While Vietnamese elites might still use Western alcohol as a marker of their distinction, at the same time they would continue to drink 'our liquor' (and even continue to eat dog meat) along with their less wealthy compatriots in the city and the countryside, and to participate in the same unruly, drunken conviviality. Thanks in part to the alcohol monopoly, 'us' continued to encompass large swathes of Vietnamese society, and ruơ $u$ and its drinking culture could serve as important points of reference for an evolving national identity.

These traditions were reinvented and reinvigorated after 1933 when, in the wake of a public campaign to reform northern Vietnam's alcohol monopoly, four indigenous distilleries were allowed to open and allocated 20 per cent of the market. ${ }^{99}$ After more than three decades of legal monopoly, it was a momentous change. Nguyễn Tuân, for example, divided the history of the alcohol market in two: before the opening of the Văn Điển distillery in Hà Đông, and after. ${ }^{100}$ Not surprisingly, advertising campaigns by the new distilleries took up a theme of tradition and stressed their

98 Thái Lương, Văn hoá rượu, pp. 88-93.

99 Gerard Sasges, “Indigenous representation is hostile to all monopolies": Pham Quynh and the end of the alcohol monopoly in colonial Vietnam', Journal of Vietnamese Studies 5, 1 (2010): 1-36.

100 Nguyễn Tuân, Tàn đèn dầu lạc [Lamp ash and groundnut oil] (Hanoi: Nhà xuất bản văn hoáthông tin, 2002) p. 103. 
liquor's authentically 'native' qualities. In 1933, the Văn Điển distillery ran a contest asking the public to submit samples of their favourite native brewer's yeast. Simultaneously evoking the nation and denigrating the modern 'factory' alcohol, the ad runs 'To make Vietnamese liquor, one must use yeast containing medicine with health benefits for drinkers'. ${ }^{101}$ The same distillery also held contests for the best câu đôi (parallel phrase poetry) lauding their liquor, and published other poems linking their product to the New Year celebrations and to the famous annual pilgrimage to Chùa Hương (the Perfume Pagoda). ${ }^{102}$ The Nam Đồng Ích distillery was more explicit, proudly labelling its product 'our liquor' and exhorting all good Vietnamese to drink their product. ${ }^{103}$ The distillery also pressed Lý Toét and his companion Xã Xệ into service. In one ad, the perennially thin old man asks his chubby friend the secret of his robust health. Xã Xệ replies that it's thanks to the way Nam Đồng Ích liquor made good food even more delicious. ${ }^{104}$ Much like Coca-Cola today, in late colonial Vietnam everything went better with rượ ta.

Yet even as these distilleries evoked a tradition they reconfigured it. While the new factories may not have been as large as Fontaine's and the resulting liquor may have been tastier, it was nonetheless an industrial product made on assembly lines with little resemblance to a village distiller and her pot bubbling away on an open hearth. The Vạn Vân distillery in Bắc Giang, for example, with 140 furnaces and 72 stills, employed more than 300 workers. The source of Xã Xệ's good health was mass-produced liquor sold by a network of licensed retailers, not prepared by a local doctor of traditional medicine. The new liquor was sold in glass bottles, not the earthenware flasks of old, and the Vạn Vân distillery carefully modelled its containers on the well-known square Cointreau bottle, an imported luxury in colonial Vietnam. One liquor distributor even ironically quoted Nguyễn Khuyến's famous poem, assuring drinkers that while good friends might be hard to find, at least now they could find delicious liquor at a reasonable price. ${ }^{105}$ Yet this reconfiguration of tradition in late colonial Vietnam would not be driven by French capitalists with names like Fontaine, but rather by Vietnamese with names like Lê, Đố, and Nguyễn. ${ }^{106}$ And while the neo-traditional drinking culture that emerged in the late

101 'Nấu rượu Nam, phải có thứ men toàn những vị thuốc bổ ích cho người uống'. The precise term used, 'Nam' [lit., south or southern] reflects the fact that the term 'Vietnam' had not yet come into common usage. The term effectively asserted a nascent national identity by deviating from the official colonial terminology of 'Annam' [Pacified South]. The ad ran throughout the summer and fall of 1933. See, for example, Phong Hoá 45 (5 May 1933): 4; http://issuu.com/nvthuvien/docs/ph_045_05_may_1933? $\mathrm{e}=5818453 / 3051823$.

102 For parallel poems, see Phong Hoá 76 (8 Dec. 1933): 4. On the New Year, see Phong Hoá 92 (6 Apr. 1934): 10; on the Perfume Pagoda, see Phong Hoá 94 (20 Apr. 1934): 12; http://issuu.com/nvthuvien/docs/ph_076_08_dec_1933?e=5818453/3051950; http://issuu.com/nvthuvien/docs/ph_092_06_ apr_1934?e=5818453/3212462; http://issuu.com/nvthuvien/docs/ph_094_20_apr_1934?e=5818453/ 2827406.

103 Once again, the term used is 'người Nam' [Southerners], but in the context best understood as 'Vietnamese'. The ad ran multiple times. See, for example, Phong Hoá 76 (8 Dec. 1933): 5; http:// issuu.com/nvthuvien/docs/ph_076_08_dec_1933? e=5818453/3051950.

104 Phong Hoá 124 (16 Nov. 1934): 5; http://issuu.com/nvthuvien/docs/ph_124_16_nov_1934? $\mathrm{e}=5818453 / 3212430$.

105 Phong Hoá 85 (11 Feb. 1934): 2; http://issuu.com/nvthuvien/docs/ph_085_11_feb_1934muaxuan? $\mathrm{e}=5818453 / 3051961$.

106 An announcement from 1934 lists Văn Điển’s board of directors as Lê Văn Phúc, Đỗ Đinh Đắc, 
colonial period owed much to the pre-colonial past, it was as much a part of a colonial modernity as red wine and champagne, new women and nhà hát ả đào, colonial repression and nationalist aspirations.

\section{Rượu and cognac}

A few days spent drinking in Vietnam today would reveal many changes since the colonial period. Thanks to the combination of rising incomes and the proliferation of ice and refrigeration, beer has replaced rice liquor as the most commonly consumed alcoholic beverage. Among locally produced distilled liquors, the largest seller is 'Vodka Hanoi', produced by a company that proudly, if incongruously, traces its origins to the founding of A.R. Fontaine's first modern factory in 1898. Today, its claims that the liquor is pure, modern and produced with the latest Western technologies seems finally to have found greater purchase with Vietnamese consumers. And whether they're drinking beer, wine, or liquor, women increasingly enter the same spaces and participate in the same practices of consumption and conviviality previously reserved for men.

At the same time, those few days of drinking and socialising would reveal strong echoes of Vietnam's past. 'Tradition', along with modernity, continues to be reinvented. In Vietnam's cities, upscale ruơu ta restaurants self-consciously imitate the spaces and practices of 'traditional' drinking. Customers sit cross-legged on bamboo mats around low tables, sharing liquor poured from terracotta flasks and eating from a menu that could include everything from the boiled greens that remain a staple of village meals to Japanese fusion cuisine. The liquor they consume might have been made by an elderly woman in a village famed for centuries for its rươu, or it might have come from a modern assembly line equipped with the latest vacuum stills. Champagne and cognac continue to be ideal markers of distinction, the price of securing a table at expensive nightclubs. And while women may now drink alcohol in public without raising an eyebrow, the culture of the nhà hát à đào lives on in everything from beer 'promotion girls' to the tens of thousands of women 'dealing in desire' every night in Vietnam's karaoke bars and exclusive clubs. ${ }^{107}$

Conviviality has also proven remarkably resilient. Almost 100 years on, the temperance advocated by colonial reformers has yet to gain much traction, and the sort of working-class/elite divide described by Bourdieu is difficult to find. Instead, the hundreds of clients that flock to the beer restaurants along Saigon's Nguyễn Trung Trực Street every evening arrive on everything from battered Honda scooters to the latest S-Class Mercedes. While the brand of beer they drink may serve to denote their status, they are all participating in a drinking culture that in many ways transcends class and links them to a pre-colonial past. One symbol of this is the Vietnamese habit - one that surely provokes horror among connoisseurs - of drinking shots of cognac from glasses with more than a passing resemblance to a chén hat mít (cup the size of a jackfruit seed). Whether drinking expensive imported liquor or home-brewed ruợ $t a$, the practices are often much the same.

Nguyễn Văn Thịnh and Đỗ Thúc Phách. Phong Hoá 99 (25 May 1934): 14; http://issuu.com/nvthuvien/docs/ph_099_25_may_1934?e=5818453/3212581.

107 Kimberly Kay Hoang, Dealing in desire: Asian ascendancy, Western decline, and the hidden currencies of global sex work (Berkeley: University of California Press, 2015). 
In part, this article has argued, this stems from colonial policies that racialised not just the different types of alcohol but also the drinking cultures that accompanied them. Thanks to the alcohol monopoly, 'our alcohol' and 'our way of drinking alcohol' have both become ways of imagining a Vietnamese identity. Yet the persistence of these forms of conviviality also reflects the unease that arose from the encounter with colonial modernity. In the image that opened this article, glasses shatter along with many of modernity's claims. The colonial reinvention of an indigenous drinking tradition served as a means for Vietnamese not only to obscure their unfamiliarity with the goods and practices that constituted colonial modernity, but also to reassert the value of social relations that sat uneasily with new ideas about consumption, individuality, equality, and gender roles. Yet there may be a third factor. Perhaps Vietnamese are just convivial people. Asked to describe themselves, they will almost inevitably reply that Vietnamese live their lives with a great deal of 'tinh cám' (a word that brings together ideas of affection, emotion, and feeling). Yet whatever the precise relation of these three factors - repressive French policies, the anxieties provoked by the encounter with colonial modernity, or Vietnamese tinh cam - the result is a place where tradition and modernity, 'our' rice liquor and 'their' cognac can all be integrated within a shared and raucous conviviality. 